Anna Kretschmer

Universität Wien

Philologisch-Kulturwissenschaftliche Universität

Lehrstuhl für Ostslawische und Russische

Sprachwissenschaft

anna.kretschmer@univie.ac.at
УДК 811.163.41:37.011.2:94

https://doi.org/10.18485/slavistika.2021.25.1.8

Оригинални научни рад примљено 07.02.2021. прихваћено за штампу 17.06.2021.

\title{
О ПРОУЧАВАњУ ПРЕДСТАНДАРДНЕ СРПСКЕ ПИСМЕНОСТИ (методолошка запажања)
}

У раду је представљен вишекомпонентни модел анализе предстандардних словенских писмених традиција са подручја тзв. Православне Славије. Модел се састоји од три дела лингвистичког, текстолошког и екстралингвистичког. Његову теоријску и методолошку основу чине радови Прашког лингвистичког кружока, посвећени специфичностима донационалних писмених језика, концепција Православне Славије и теорија диглосије као језичке ситуације у њој. Модел је већ био примењен на корпусу текстова на српском језику и источнословенским језицима. Нарочита пажња поклања се завршном периоду старе православне словенске културе и процесима преласка ка културном моделу Западне Европе у 17-18. веку (за српско подручје и почетком 19. века). У раду се предлаже типолошки приступ ареалу Православне Славије, при чему се издвајају два прототипа - матични и енклавни („острвни”).

Кључне речи: предстандардна писменост, Православна Славија, диглосија, славеносрпски, методолошки поступак моделирања.

The main topic of this paper is the older, pre-national periods of Slavic literature and the methodological aspects of their research. For this purpose a model with three levels and multiple parametres has been developed by the author of this paper. The starting point of the analysis is the text as a whole. According to that, the analysis includes linguistic as well as textological and extralinguistic features of the text. The model is based on the remarks of the Prague linguists about the nature of older literature, on the conception of the so-called Slavia Orthodoxa and on the theory of diglossia as the main language situation of Slavia Orthodoxa. The model has been applied on Serbian and Eastern Slavic textual corpora, with special consideration of the last period of common Orthodox Slavic literature: $17^{\text {th }}$ - early $19^{\text {th }}$ centuries. For the Serbian area that is the so-called Slavonic Serbian literature and culture, a subject that has not been adequately researched yet. The paper also presents a typological approach to Slavia Orthodoxa, with two main types of culture, a "motherland" type - and an "insular" type.

Keywords: model, older Slavic literatures, Slavia Orthodoxa, diglossia, Slavonic Serbian, methodological aspects.

У центру пажње анализе налазе се истраживања посвећена раздобљу српске писмености уочи Вукове реформе и формирања савременог српског стандардног језика. Тај период још није довољно истражен. Да би му се адекватно научно приступило од нарочите је важности методолошки апарат, који, међутим, још не постоји. Зато се у фокусу овог рада налазе методолошки аспекти проучавања донационалних писмених језика. Већ у радовима Прашког лингвистичког кружока упозорава се на специфичне одлике тих језика. Као њихова битна обележја наводе се уска социјална база и надетнички карактер. Другим речима, тим језицима се служио само ограничени круг школоване елите - и то у више друштава, односно етноса. То су обично истовремено били језици 
цркве и вере (уп. Jedlička 1978: 53). Међутим, историји словенских писмених традиција се обично приступа у границама савремених, националних језика. Такав методолошки поступак настао је у културној и научној парадигми у доба романтизма, које је за више словенских етноса (тада претежно мањина у туђем окружењу) било и доба културне и језичке еманципације - стога се оно означава и као Словенски (нациионални) препород. У тадашњем социокултурном контексту такав приступ је био разумљив и донекле сврсисходан, али се он данас не може сматрати методолошки адекватним.

Савремени стандардни језици не могу се, дакле, узимати као детерминанта у погледу старијих фаза културно-језичке историје (уп. Havránek 1963: 346348; Гавранек 1971: 344). Важан корак у напредовању методологије таквих истраживања представља концепција Православне Cлавије (Slavia Orthodoxa), која је била формулисана у радовима Никите Толстоја (Толстой 1961, 1979; уп. такође Кречмер 1996) и Рикарда Пикија (Ріcchio 1962, 1991) - на основу битних обележја, по којима се стара културна парадигма код Православних Словена разликује од оних у неправославној Славији (тзв. Slavia Latina, односно Slavia Romana) и у несловенској Европи. За старије епохе у Западној Европи и код неправославног словенства била је, поред регионалне, карактеристична социјална диференцијација културних модела - истовремено су постојале социјално детерминисане супкултуре двора и племства, града, односно грађанског урбаног становништва, школе (пре свега у односу на више и високо школство уп. тзв. школску драму), села итд. За разлику од њих, Православна Славија је представљала у погледу писмене културе хомогени ареал, готово непромењив у времену и простору све до новог доба.

Жанровски репертоар писмености Православне Славије био је подређен сакралној доминанти и њоме одређен - Никита Толстој формулисао је на основу тога строго хијерархијски организован жанровски канон православне словенске писмености који садржи 14 рубрика и то у непосредној зависности од степена сакралности дотичног жанра (Толстой 1988). Прве четири рубрике, врх овог хијерахијског модела, чине (наведеним редоследом) литургијска, химнографска, хагиографска (житијна) и панегиричка писменост - док последња три ранга заузимају световно-правна, административна и свакодневна писменост (Толстой 1988: 168) - тј. утилитарна писменост којом се служило у сврхе администрације, права и сл. Међутим, она не спада у оно заједничко културно благо Православне Славије, већ припада области световног живота и показује битне регионалне разлике и у питању језичке припадности. Тако, на пример, код Источних Словена старословенски (односно црквенословенски) није успео да продре у домен те утилитарне писмености, док је код православних Јужних Словена старословенски, до одређене мере, то успео. Разлози таквих (и других) разлика још нису познати - али и сразмерно ретко представљају предмет научног истраживања, и свакако захтевају посебан приступ. Сем тога, такви жанрови - закони, државни уговори, тестаменти и сл. из више разлога треба да се разматрају одвојено како од заједничког духовног текстуалног наслеђа православне Славије тако и од усмене фоклорне културе - јер представљају појаве које се суштински од њих разликују у погледу интенционалности, језика, структуре и др. 
Од централног је значаја готово искључиво сакрални карактер заједничке православне писмене словенске културе. Тиме је био одређен и жанровски репертоар, у којем дуго нису (или јесу, али тек маргинално) били заступљени световни жанрови, белетристика. Такве и друге жанрове пружила је регионална усмена фолклорна култура - која такође није била социјално детерминисана. Другим речима, православни Словени без обзира на своју социјалну припадност били су корисници углавном бинарног културног модела - један његов саставни део чинила је сакрална писменост, а други - усмена народна култура.

Заједничка писмена култура, присно везана за веру, служила се заједничким језиком - црквенословенским одговарајућих локалних редакција, док су у усменој употреби били локални идиоми. Таква ситуација представља посебну врсту билингвизма - диглосију (у схватању Успенског (Успенский 1983) и Фергусона (Ferguson 1959)). Оба језичка субсистема се при том налазе у ситуацији комплементарне функционалне дистрибуције, чиме се начелно искључује њихова коегзистенција у истом функционалном контексту - а тиме и конкуренција (уп. Толстој 1981, 1998). То чини диглосију стабилном - за разлику од обичног билингвизма у којем увек долази до доминирања једног језичког субсистема над другим. Фактор стабилности културног модела Православне Славије обезбеђивао је и изузетно високи статус и углед црквенословенског језика као језика вере и цркве. Другим речима, у основи јединства писмене културе и њеног језика било је јединство вере, чиме су и била одређена основна дистинктивна обележја те православне писмене културе. Ван домена црквенословенског језика налазила се световна, пре свега утилитарна, писменост, углавном развијана на бази локалних идиома.

На основу горепоменутих и других радова (нарочито Живова (Живов 1996), Хитл-Фолтера (Хюттль-Фольтер 1978), Хитл-Ворта (Нüttl-Worth 1978), Исаченка (Issatschenko 1975, 1980), Лихачова (Лихачев 1963, 1968)) формулисали смо модел за истраживање предстандардних фаза православне словенске писмености (уп. Kretschmer1989; Кречмер 1991, 2000, 2013). Таква временска одредница није случајна - ради се о завршној фази старе православне словенске културе на тим подручјима и о почетку преласка на културни модел новог доба. Тај период је изузетно занимљив и изнијансиран - али је, нажалост, сразмерно слабо проучен. Као почетак прелазне фазе оквирно се може сматрати 17. век, иако се временске границе (и у погледу краја те фазе) могу битно разилазити у појединим регионима.

Завршни период поменуте фазе код Срба обично се везује за појам славеносрпски. Међутим, у србистици још увек не постоји консензус ни у погледу природе те појаве, нити у погледу њених временских, жанровских, интенционалних, односно језичких обележја (уп. Грицкат 1996, 1987; Толстой 1978, 1879; Кречмер 1990, 2007б; Unbegaun 1935). Консензус постоји, међутим, у погледу негативног става према славеносрпском - и до данас без знања о томе шта је тај славеносрпски уствари био. Не осврћући се даље на ово питање, приказаћемо укратко феномен славеносрпског пре него што се обратимо самом моделу. Тај појам се употребљава за посебну културну и писмену традицију коју су формирали и користили Срби након Велике сеобе у свом новом завичају као поданици Хабзбуршке царевине. Ова традиција постојала је укупно од 
1760-их до 1840-их година и оставила иза себе огроман корпус текстова широког жанровског репертоара. У то доба то је био готово једини извор световне српске писмене културе, књижевности и образовања - јер је на српским просторима под турском владом ситуација била прилично неповољна за било коју културну делатност. Стара православна култура овде није нестала, иако је све више стагнирала, а у 17. веку већ почела да се полако гаси. Срби у Аустрији су, напротив, успели да формирају ново, урбаније друштво са одређеним слојем школоване и родољубиве елите.

У наставку бисмо желели укратко да представимо наш модел, са посебним освртом на методолошке постулате. Писмене манифестације језика увек представљају више од лингвистичке појаве. У анализи треба, дакле, узимати у обзир и њихове ванјезичке особине. Зато свирсисходним сматрамо узети као непосредан предмет и полазну тачку анализе текст као целину, при чему би се у анализу укључивале све његове особине. Анализа при томе има начелно дескриптивни, описни, а не евалуативни карактер, бар у почетној својој фази: систематски се описују све особине дотичног текста. Такав приступ пружа адекватну базу за глобалнији циљ истраживања - реконструкцију језичке и културне ситуације у прошлости, као и светоназора човека и социјума. Таква реконструкција, свакако, представља веома захтеван подухват. Али само тако ћемо моћи да доспемо до поузданих података како о књижевно-језичким парадигмама прошлих векова тако и о сазнању, виђењу и схватању језика, културе - тиме и живота, завичаја и света у појединим раздобљима и друштвима (уп. Кречмер 2012). То се може остварити само када се из аналитичког поступка искључи механистичко и научно неоправдано априорно преношење данашње језичке ситуације на стање у прошлости.

С обзиром на сложену природу писмених манифестација језика, модел укључује више параметара и састоји се (у актуелној верзији) од три дела:

1. Лингвистичка анализа;

2. Текстолошка анализа;

3. Ванјезичка анализа (са посебним освртом на социолингвистичке параметре). ${ }^{1}$

Лингвистичка анализа се спроводи на бази што потпуније дескрипције појединачних језичких нивоа, и то свих - иако су се током истраживања нарочито значајним показале лексика и синтакса. ${ }^{2}$ Разматра се и атрибуција, односно порекло појединих језичких елемената - али на нивоу дескрипције, тј. без априорне евалуације.

Током досадашњих истраживања, следећи параметри текстолошке анализе показали су се као најважнији.

Жанр (врста текста) и његова интенција је параметар од нарочитог значаја управо за период промене културне парадигме. При томе се проверава да ли

\footnotetext{
${ }^{1}$ Тренутно се разрађује и четврти - етнолингвистички, односно лингвокултуролошки део анализе.

2 УП. о предности синтаксе у дијахронијским истраживањима у: Hüttl-Folter 1978; уп. так. Кречмер 2007a.
} 
се и како мења жанровски репертоар - обично у размаку од двадесет пет (нпр. на почетку 18. века - у односу на писменост Срба у Аустрији), односно десет година. Основни параметар анализе текстуалне продукције у прошлости била је опозиција духовна : световна писменост. Анализа је, бар у односу на старије доба (у којем доминирају духовни текстови), углавном заснована на горепоменутом моделу жанровског канона Никите Толстоја (Толстой 1988) који се емпиријски проверава и модификује на основу добијених резултата. У погледу световне писмености, битан параметар је интенција, и то у смислу опозиције - текстови са просветном и поучном интенцијом : текстови без такве интенције (белетристика у ужем смислу). Истовремено се спроводи дескрипција целокупног жанровског репертоара у дотичној фази уз анализу фреквентности појединих жанрова.

Анализа је бидирекционална и оба њена правца се налазе у дихотомијском односу:

(a) текстолошка експертиза конкретних текстова - као база за анализу корпуса;

(б) анализа целокупног корпуса тесктова поменутог периода.

У фази промене културне и књижевне парадигме редовно долази до преузимања страних предложака и то како у облику појединих текстова тако и жанрова у целини. Такви предлошци, узорци могу да се преузимају путем превода, али и адаптацијом и имитацијом. Овај параметар је стога исто укључен у анализу, а истражује се и његова динамика - да ли се и колико мења удео превода, адаптација, имитација. Узима се у обзир и корелација између таквих текстова и оригиналне тесктуалне продукције.

Током истраживања се испоставило да Уводи, Предговори различите врсте и функционално слични делови текста треба да се анализирају засебно - јер у њима у прелазно доба по правилу долази до изражаја позиција аутора односно преводиоца.

Још један саставни део текстолошке анализе представља стил текста односно жанра (у погледу последњег - у синхроном и дијахроном аспекту) - при чему се у анализу укључује и квантитативни, односно фреквенцијски параметар (уп. Кречмер 2004). Ефикасним се показало укључивање параметара текстуалне кохезије и кохеренције, тј. савремене текстовне лингвистике. Такав поступак доприноси објективнијој анализи корпуса, нарочито када је у питању доба пре кодификације и стандардизације.

Екстралингвистичка компонента модела хетерогенија је него друге две. У актуелној верзији она се састоји од следећих параметара:

- Временска и локална карактеристика текста;

- Личност аутора (преводиоца, адаптатора) са релевантним социолингивстичким подацима: порекло/породица, школовање, његово стваралаштво (пре свега жанровски репертоар), став у полемици око стварања новог (српског) писменог језика; ${ }^{3}$

\footnotetext{
${ }^{3}$ Процесу непосредног активног формирања нових књижевних језика код православних Словена по правилу је претходила језичка полемика у којој је једно од централних питања представљала улога и статус црквенословенског језичког наслеђа у тим новим језицима.
} 
- Намена текста, односно интендирани круг реципијената;

- Фактичка рецепција текста у друштву одговарајућег периода;

Емпиријску базу анализе чине три велика корпуса световне писмености позне Православне Славије. То су, хронолошким редоследом:

- Руска приватна преписка из 17. и са почетка 18. в. (1603-1731. г.) (уп. Кречмер 2002, 2009, 2018).

- „Славеносрпске хронике” Ђорђа Бранковића (настале током 1690-их и 1700-их г. - њихов аутор се упокојио у децембру 1711. г.) (уп. Кречмер 2005).

- Славеносрпска писменост (око 1760. - око 1840. г.) (уп. Кречмер 1990, 2007б).

Централну ознаку културног модела Православне Славије представља, као што је већ поменуто, његова хомогеност, сакралност и изражена стабилност у времену и простору. У поређењу са неправославним старијим словенским културама, као и са западноевропском, Православна Славија заиста наступа као монолит, као јединство. Стога се ова ознака и даље може сматрати као инваријанта - у општеевропском културном контексту. Међутим, Православна Славија је поседовала и унутрашњу диференцијацију, нарочито у позним својим епохама (уп. Кречмер 2015). Таква варијабилност била је детерминисана пре свега околностима конкретног историјског контекста датог региона и доба.

Овде ћемо представити само један аспект ове тематике, специфичности тзв. енклавних (односно ексклавних, тзв. острвских) култура у поређењу са тзв. матичним културама, у којима се углавном чува стара културна парадигма. У прву групу спадају културе источних Словена у пољско-литванској држави и Срба у аустријским земљама а у другу Московска Русија и средњовековна Србија. ${ }^{4}$ У матичним ареалима су православни Словени представљали већински живаљ у већински моноконфесионалном и монојезичном окружењу. У енклавним ситуацијама они су били мањина, стално изложена утицајима и притисцима од стране доминантног окружења, неретко туђег у етничком, језичком, културном и верском погледу.

Наша истраживања показују да су разлике између та два типа битне, чак суштинске и у извесном смислу још увек непревазиђене. Оне се манифестују у више погледа, поред осталог, у погледима на писану културу и њен језик, на однос између те културе и вере (цркве), у погледу на школу, на жанровски састав књижевности и писмености, на однос према западној културни и образовном моделу - све до погледа на глобална питања светоназора - схватања света и себе. Полазна тачка и непосредни објекат истраживања и у погледу ове тематике представљају конкретни текстови у целини својих језичких и ванјезичких особина.

Као најважнији резултати досадашњих истраживања варијабилности старе Православне Славије могу се навести следећи.

Као најконзервативнији тип показује се Московска Русија што је, свакако, условљено околностима њене историје. Ова, након турских освајања и пада

\footnotetext{
${ }^{4}$ Али већином и српски предели под турском влашћу, јер се матични тип углавном и ту задржава.
} 
Цариграда задуго једина независна православна држава, све више се осећа угроженом од стране суседних друштава и држава и то пре свега у верском погледу. У таквом се контексту почетком 16. века развија доктрина о Москви као трећем (и последњем) Риму, као ослонцу праве вере (након што су прва два нестала због њене издаје) и у вези са тиме се уводи политика свесне и усмерене затворености друштва, минимализације контаката са Западом - који се у одређеном смислу чак сматра већом опасношћу од муслиманских Турака и Татара.

Нешто другачије текао је развој на српским подручјима. Током турских освајања стара културна парадигма ту није много настрадала - сем што, свакако, није била у прилици ни да се развија. Она и даље постоји, али све више стагнира. А од 17. века се већ може говорити о њеном опадању - иако не и о пропадању. У једном погледу постоји ипак сличност између Московске Русије и Срба под турском влашћу - то је прекид некадашњих контаката са Западном Европом и Византијом.

Стара културна традиција није нестала ни у енклавним културама, али долази до битних промена јер је словенски живаљ ту био у ситуацији перманентног и вишевековног контакта традиционалне и (доминантне) западноевропске културе. Као значајни параметар у анализи таквих словенских култура показали су се школство и просвета у целини. Наиме, приступ образовању за православне Словене у страном окружењу био је могућ само преко западних, претежно латинских школских установа, а напредак у послу - готово само ван граница православног словенског завичајног живота. Образовани Словени у туђем окружењу, чувајући свој верски и етнички идентитет, све више су примали обележја западноевропског културног типа.

Насупрот томе, Московска Русија је свесно и намерно сама себе искључавала из токова светске политике и историје. Животни контекст био је максимално фокусиран на микросвет у границама шире породице и завичаја. Ни виши слојеви нису се осећали као политички агенси, као грађани, нити су се уопште интересовали за политику своје државе, а камоли за шири политички контекст ван њених граница. Ове разлике се добро виде када се упореди приватна преписка Московске Русије у предпетровско и петровско доба с једне стране, и „Славеносрпске хронике” Ђорђа Бранковића, савременика већине учесника те преписке, с друге (уп. Кречмер 2002, 2006, 2009, 2018).

Као резултат реформаторске делатности Петра Великог, руско друштво се током 18. века битно и суштински променило. Као већински живаљ у независној држави оно се налазило у много бољој социолингвистичкој и социокултурној ситуацији него Срби, било под аустријском, било под турском влашћу, па је зато нова руска културна и књижевно-језичка парадигма могла неометано да се развија, иако под утицајем западноевропског (испрва претежно немачког, касније француског) модела.

Славеносрпска културна и језичка парадигма показује читав низ подударности са руском истог периода. Да се није појавио Вук Караџић, можда би се и српски стандардни језик створио по обрасцу блиском руском, тј, као језички стандард амалгамног типа у којем се пластично претапају и преплићу елементи више језика и култура (уп. Krečmer 2012). 
Основни циљ и намена овога рада састојали су се у настојању да се покаже важност приступа историји словенских књижевних и стандардних језика и писмених традиција у ширим границама како целокупног словенског света тако и целокупне Европе, те једног широко схваћеног филолошког приступа који превазилази како границе појединих националних савремених језичких стандарда тако и границе саме лингвистике.

\section{Цитирана литература}

Гавранек, Богуслав. «Задачи литературного языка и его культура». [B:] Prager linguistischer Zirkel (Slavische Propyläen 108). München: Wilhelm Fink Verlag, 1971: 338-377.

[Havránek, Bohuslav. „Zadači literaturnogo jazyjka i ego kul’tura“. [V:] Prager linguistischer Zirkel (Slavische Propyläen 108). München: Wilhelm Fink Verlag, 1971: 338377]

Грицкат, Ирена. „У чему је значај и какве су специфичности славеносрпског периода у развоју српскохрватског језика. Поводом иницијативе Матице Српске да се састави речник књижевног језика славеносрпског периода“. Зборник Матице Српске за филологију и лингвистику IX, 1966: 61-66.

[Grickat, Irena. „U čemu je značaj i kakve su specifičnosti slavenosprskog perioda u razvoju srpskohrvatskog jezika. Povodom inicijative Matice Srpske da se sastavi rečnik književnog jezika slavenosrpskog perioda“. Zbornik Matice Srpske za filologiju i lingvistiku IX, 1966: 61-66]

Грицкат, Ирена. „Још нека питања у вези са славеносрпском епохом“. Јужнословенски филолог XLIII, 1987: 111-135.

[Grickat, Irena. „Još neka pitanja u vezi sa slavenosrpskom epohom“. Južnoslovenski filolog XLIII, 1987: 111-135]

Живов, Виктор М. Язык и культура в России XVIII века. Москва: Языки Славянской Культуры, 1996.

[Živov, Viktor M. Jazyk i kul'tura v Rossii XVIII века. Moskva: Jazyki Slavjanskoj Kul'tury, 1996]

Кречмер, Ана. „Неколико напомена поводом 30-годишњег јубилеја истраживања славеносрпског доба“. Зборник Матице Српске за филологију и лингвистику XXXIII, 1990: 221-231.

[Krečmer, Ana. „Nekoliko napomena povodom 30-godišnjeg jubileja istraživanja slavenosrpskog doba“. Zbornik Matice Srpske za filologiju i lingvistiku XXXIII, 1990: 221-231]

Кречмер, Ана. „Методологија разрађивања лингвистичких текстовних модела за предстандардно-језичко доба“. Научни састанак слависта у Вукове дане 20/2, 1991: 65-71.

[Krečmer, Ana. „Metodologija razrađivanja lingvističkih tekstovnih modela za predstandardno-jezičko doba“. Naučni sastanak slavista u Vukove dane 20/2, 1991: 65-71]

Кречмер, Ана. „О феномену тзв. Рах Slavia Orthodoxa у контексту историје словенских стандардних језика“. Научни састанак слависта у Вукове дане 25/2, 1996: 31-39.

[Krečmer, Ana. „O fenomenu tzv. Pax Slavia Orthodoxa u kontekstu istorije slovenskih 
standardnih jezika“. Naučni sastanak slavista u Vukove dane 25/2, 1996: 31-39]

Кречмер, Ана. „О књижевно-језичкој традицији до 1800. код Срба и Руса (размишљања о словенској историјској стандардизацији)“. Јужнословенски филолог (In memoriam P. Ivić) LVI/12, 2000: 543-559.

[Krečmer, Ana. „O književno-jezilkoj tradiciji dо до 1800. kod Srba i Rusa (razmišljanja o slovenskoj istorijskoj standardizaciji)“. Južnoslovenski filolog (In memoriam P. Ivić) LVI/12, 2000: 543-559]

Кречмер, Ана. „Руско приватно писмо у 17. веку и у доба Петра Великог“. Зборник Матице Српске за славистику 62, 2002: 117-148.

[Krečmer, Ana. „Rusko privatno pismo u 17. veku i u doba Petra Velikog“. Zbornik Matice Srpske za slavistiku 62, 2002: 117-148]

Кречмер, Ана. „Формирање функционалних стилова у српској писмености у доба Вукових реформи“. Научни састанак слависта у Вукове дане 32/1, 2004: 201-210.

[Krečmer, Ana. „Formiranje funkcionalnih stilova u srpskoj pismenosti u doba Vukovih reformi“. Naučni sastanak slavista u Vukove dane 32/1, 2004: 201-210]

Кречмер, Ана. „Српски језик између старог и новог доба (о језику „Хроника“ Ђ. Бранковића)“. Научни састанак слависта у Вукове дане 34/1, 2005: 43-53.

[Krečmer, Ana. „Srpski jezik između starog i novog doba (o jeziku „Hronika“ Đ. Brankovića)“. Naučni sastanak slavista u Vukove dane 34/1, 2005: 43-53]

Кречмер, Ана. „Културне парадигме код Срба и Руса на прелазу од средњовековног ка новом добу“. [У:] Сусрет култура. Зборник радова. Нови Сад: Универзитет у Новом Саду, 2006: 493-500.

[Krečmer, Ana. „Kulturne paradigme kod Srba i Rusa na prelazu od srednjovekovnog ka novom dobu“. Susret kultura. [U:] Zbornik radova. Novi Sad: Univerzitet u Novom Sadu, 2006: 493-500]

Кречмер, Ана. „О синтакси предстандардних фаза језичког развоја на материјалу српске и руске писмености“. Зборник Матице Српске за славистику 71-72, 2007a: 465-480.

[Krečmer, Ana. „O sintaksi predstandardnih faza jezičkog razvoja na materijalu srpske i ruske pismenosti““. Zbornik Matice Srpske za slavistiku 71-72, 2007a: 465-480]

Кречмер, Ана. „Славеносрпска писменост и њено значење за историјску србистику“. [У:] Шездесет година института за српски језик САНУ. Зборник радова I. Београд: Институт за српски језик САНУ, 2007б: 313-320.

[Krečmer, Ana. „Slavenosrpska pismenost i njeno značenje za istorijsku srbistiku“. Šezdeset godina Instituta za srpski jezik SANU. [U:] Zbornik radova I. Beograd: Institut za srpski jezik SANU, 2007b: 313-320]

Кречмер, Анна. «Картина мира Православной Славии накануне Нового времени (на русском и сербском материале)». [В:] Е. Л. Березович и др. (ред.) Этнолингвистика. Ономастика. Этимология. Материалы II Международной научной конференции. Екатеринбург, 8-10 сентября 2012 г. Екатеринбург: Изд-во Уральского университета, 2012: 29-30.

[Krečmer Anna. „Kartina mira Pravoslavnoj Slavii nakanune Novogo vremeni (na russkom i serbskom materiale)“. [V:] E. L. Berezovič i dr. (red.) Ėtnolingvistika. Onomastika. Ėtimologija. Materialy II Meždunarodnoj naučnoj konferenci. Ekaterinburg, 8-10 sentjabrja 2012 г. Ekaterinburg: Izd-vo Ural'skogo universiteta, 2012: 29-30]

Кречмер, Анна. «Вопросы методологии исследования достандартноязыковой (славянской) письменности». [В:] Е. С. Суркова, Е. Н. Руденко (ред.) Современные 
направления исследования и преподавания славянских языков. Международная научная конференция «VIII Супруновские чтения» (Минск, 21-22 сентября 2012 г.). Сборник научных статей. Минск: БГУ, 2013: 113-122.

[Krečmer, Anna. „Voprosy metodologii issledovanija dostandartnojazykovoj (slavjanskoj) pis'mennosti““. [V:] E. S. Surkova, E. N. Rudenko (red.) Sovemennye napravlenija issledovanija i prepodavanija slavjanskich jazykov. Meždunarodnaja naučnaja konferencija „VIII Suprunovskie čtenija““ (Minsk, 21-22 sentjabrja 2012 g.). Sbornik naučnych statej. Minsk: BGU, 2013: 113-122]

Кречмер, Анна. «Православные славяне в неправославном окружении - проблемы культурно-языкового идентитета». [В:] Языковой контакт. Сборник научных статей. Минск: РИВШ, 2015: 101-110.

[Krečmer, Anna. „Pravoslavnye slavjane v nepravoslavnom okruženii“ - problemy kul'turno-jazykovogo identiteta“. [V:] Jazykovoj kontakt. Sbornik naučnych statej. Minsk: RIVŠ, 2015: 101-110]

Кречмер, Анна. «Человек за письмом (русский человек Петровского времеми в частной переписке)». [B:] J. Besters-Dilger, F. Poljakov (Hg.) Die russische Sprache und Literatur im 18. Jahrhundert: Tradition und Innovation - Русский язык и литература в XVIII веке: традиция и инновация (Gedenkschrift für G. Hüttl-Folter). Русская культура в Европе - Russian Culture in Europe 5. Frankfurt/M. u. а. O.: Peter Lang, 2009: 267-287.

[Krečmer, Anna. „Čelovek za pis'mom (russkij čelovek Petrovskogo vremeni v častnoj perepiske)“. [V:] J. Besters-Dilger, F. Poljakov (Hg.) Die russische Sprache und Literatur im 18. Jahrhundert: Tradition und Innovation - Russkij jazyk i literatura v XVIII veke: tradicija i innovacija (Gedenkschrift für G. Hüttl-Folter). Russkaja kul'tura v Evrope - Russian Culture in Europe 5. Frankfurt/M. u. a. O.: Peter Lang, 2009: 267-287]

Кречмер, Анна. «Макро- и микромир русского человека поздней Московской Руси (на материале частной переписки)». [В:] Е. Н. Руденко, А. А. Кожинова (ред.) In Honorem (сборник статей к 90-летию А. Е. Супруна). Минск: РИВШ, 2018: 133-145.

[Krečmer, Anna. „Makro- i mikromir russkogo čeloveka pozdnej Moskovskoj Rusi (na materiale častnoj perepiski)“. [V:] E. N. Rudenko, A. A. Kožinova (red.) In Honorem (sbornik statej k 90-letiju A. E. Supruna). Minsk: RIVŠ, 2018: 133-145]

Лихачев, Дмитрий С. «Система литературных жанров Древней Руси». [B:] Славянские литературы. V Международный съезд славистов. Доклады советской делегации. Москва: Наука, 1963: 47-70.

[Lichačev Dmitrij S. „Sistema literaturnych žanrov Drevnej Rusi“. [V:] Slavjanskie literatury. V Meždunarodnyj s'”ezd slavistov. Doklady sovetskoj delegacii. Moskva: Nauka, 1963: 47-70]

Лихачев, Дмитрий С. «Древнеславянские литературы как система». [В:] Славянские литературы. VI Международный съезд славистов. Доклады советской делегации. Москва: Наука, 1968: 5-48.

[Lichačev, Dmitrij S. „Drevneslavjanskie literatury kak sistema“. Slavjanskie litratury. VI Meždunarodnyj s' ezd slavistov. Doklady sovetskoj delegacii. Moskva: Nauka, 1968: 5-48]

Толстой, Никита И. «К вопросу о древнеславянском языке как общем литературном языке южных и восточных славян». Вопросы языкознания 1, 1961: 52-66. 
[Tolstoj, Nikita I. „K voprosu o drevneslavjanskom jazyke kak obščem literaturnom jazyke južnych i vostočnych slavjan“. Voprosy jazykoznanija 1, 1961: 52-66]

Толстой, Никита И. «Литературный язык у сербов в конце XVIII - начале XIX в.» Национальное возрождение и формирование славянских литературных языков. Москва: Наука, 1978: 269-328.

[Tolstoj, Nikita I. „Literaturnyj jazyk u serbov v konce XVIII - načale XIX v.“ Nacional'noe vozroždenie i formirovanie slavjanskich literaturnych jazykov. Moskva: Nauka, 1978: 269-328.]

Толстой.Никита И. «Литературный язык у сербов в XVIII в. (до 1780 г.)». [В:] Славянское и балканское языкознание. История литературных языков и письменность. Москва: Наука, 1979: 154-201.

[Tolstoj, Nikita I. „Literaturnyj jazyk u serbov v XVIII v. (do 1780 g.)“. [V:] Slavjanskoe i balkanskoe jazykoznanie. Istorija literaturnych jazykov i pis'mennost'. Moskva: Nauka, 1979: 154-201.]

Толстой, Никита И. „Конкуренција и коегзистенција норми у књижевном језику XVIII в. код Срба“. Научни састанак слависта у Вукове дане 10/1, 1981: 33-40.

[Tolstoj, Nikita I. „Konkurencija i koegzistencija normi u književnom jeziku XVIII v. kod Srba“. Naučni sastanak slavista u Vukove dane 10/1. Beograd: Međunarodni slavistički centar, 1981: 33-40]

Толстой, Никита И. «Отношение древнесербского книжного языка к старославянскому языку». [В:] Толстой Н. И. История и структура славянских литературных языков. Москва: Наука, 1988: 164-173.

[Tolstoj, Nikita I. „Otnošenie drevneserbskogo knižnogo k staroslavjanskomu jazyku“. [B:] Tolstoj N. I. Istorija i struktura. Moskva: Nauka, 1988: 164-173]

Толстой, Никита И. «Slavia Orthodoxa и Slavia Latina - общее и различное в литературно-языковой ситуации». Вопросы языкознания 2, 1997: 16-23 (= Избранные труды. Том II. Славянская литературно-языковая ситуация. Москва: Наука, 1998: 30-42).

[Tolstoj, Nikita I. „Slavia Orthodoxa i Slavia Latina - obščee i različnoe v literaturnojazykovoj situacii“. Voprosy jazykoznanija 2, 1997: 16-23 (= Izbrannye trudy. Tom II. Slavjanskaja literaturno-jazykovaja situacija. Moskva: Nauka, 1998: 30-42)]

Успенский, Борис А. «Языковая ситуация Киевской Руси и ее значение для истории русского литературного языка». [В:] IX Международный съезд славистов. Доклады. Москва: Наука, 1983.

[Uspenskij, Boris A. "Jazykovaja situacija Kievskoj Rusi i ee značenie dlja istorii russkogo russkogo literaturnogo jazyka“. [V:] IX Meždunarodnyj s" ezd slavistov. Doklady. Moskva: Nauka, 1983.]

Хюттль-Фольтер, Герта. «Диглоссия в Древней Руси». Wiener Slawistisches Jahrbuch 24, 1978: 108-123.

[Hüttl-Folter, Gerta. „Diglossija v Drevnej Rusi“. Wiener Slawistisches Jahrbuch 24, 1978: 108-123.]

Хюттль-Фольтер, Герта. «Проблематика языкового наследия XVII века в русском литературном языке нового времени (XVIII в.)». Wiener Slawistisches Jahrbuch 28, 1982: 9-24.

[Hüttl-Folter, Gerta. "Problematika jazykovogo nasledija XVII veka v russkom literaturnom jazyke novogo vremeni (XVIII в.)“. Wiener Slawistisches Jahrbuch 28, 1982: 9-24.]

Хюттль-Фольтер, Герта. «Языковая ситуация Петровской эпохи и возникновение русского литературного языка нового типа». Wiener Slawistisches Jahrbuch 33, 
1987: 7-21.

[Hüttl-Folter, Gerta. ,Jazykovaja situacija Petrovskoj èpochi i vozniknovenie russkogo literaturnogo jazyka novogo tipa“. Wiener Slawistisches Jahrbuch 33, 1987: 7-21.]

Ferguson, Charles. "On Diglossia”. Word 15, 1959: 325-359.

Havránek Bohuslav. Studie o spisovném jazyce. Praha: Ceskoslovenské akademie věd, 1963.

Hüttl-Worth, Gerta. "Zum Primat der Syntax bei historischen Untersuchungen des Russischen". Studia Linguistica Alexandro Vasilii filio Issatschenko a collegis amicisque oblata. Lisse: Peter de Ridder Press, 1978: 187-190.

Issatschenko, Alexander. Mythen und Tatsachen über die Entstehung der russischen Literatursprache. Österreichische Akademie der Wissenschaften. Philosophischhistorische Klasse. Sitzungsberichte, 298. Bd., 5. Abhandlung. Wien: Verlag der Österreichischen Akademie der Wissenschaften, 1975.

Issatschenko, Alexander. Geschichte der russischen Sprache. Heidelberg: Carl Winter Universitatsverlag. Bd. 1, 1980; Bd. 2, 1983.

Jedlička, Alois. Die Schriftsprache in der heutigen Kommunikation. Leipzig: VEB Verlag Enzyklopädie, 1978.

Kretschmer, Anna. Zur Methodik der Untersuchung älterer slavischer schriftsprachlicher Texte (am Beispiel des slavenoserbischen Schrifttums). Slavistische Beiträge 241. München: Kubon \& Sagner, 1989.

Krečmer, Ana. „Šta bi bilo da nije bilo Vuka?“ [Y:] G. Ilić Marković, A. Kretschmer, M. Okuka (Hg.) An den Anfängen der serbischen Philologie. Salo debeloga jera libo azbukoprotres von Sava Mrkalj (1810-2010) - на почецима српске филологије. Сало дебелога јера либо азбукопротрес Саве Мркаља (1810-2010). Philologica Slavica Vindobonensia. Bd. 1. Frankfurt/Main u. a O.: Peter Lang, 2012: 281-285.

Picchio, Riccardo. „Die historisch-philologische Bedeutung der kirchenslavischen Tradition". Welt der Slaven VII, 1962: 1-27.

Picchio, Riccardo. Litteratura della Slavia ortodossa (IX-XVIII sec.). Bari: Dedalo, 1991. Unbegaun, Boris O. Les débuts de la langue littéraire chez les Serbes. Paris: Champion, 1935.

\title{
Анна Кречмер
}

\section{К ИЗУЧЕНИЮ ДОСТАНДАРТНОЙ СЕРБСКОЙ ПИСЬМЕННОСТИ}

(методологические замечания)

\begin{abstract}
Резюме
В работе предлагается многокомпонентная модель анализа предстандартных письменных традиций на территории Православной Славии. Как известно, письменность этого ареала показывает, в сравнении с неправославными славянскими и западно-европейской культурами, ряд принципиальных различий. С учетом особенностей объекта изучения модель включает как собственно языковые, так и текстологические и экстралингвистические данные, а исходной точкой анализа является конкретный текст. Текстовый корпус представлен свет-
\end{abstract}


ской письменностью заключительного периода существования Православной Славии, т. е. XVII-XIX вв. в сербском (т. н. славяносербский) и частично восточно-славянском ее ареалах. Методологический аппарат модели базируется на разработках Пражского лингвистического кружка о специфике донациональных письменных языков, на концепции Православной Славии как единого в отношении письменной культуры - и принципиально отличного от неправославных славянских и западно-европейской культур - ареала, а также на концепции диглоссии (в понимании Фергюсона и Успенского) как многовековой языковой ситуации Православной Славии. Последний раздел работы посвящен типологическому подходу к изучению Православной Славии, особенно в отношении ее внутренней дифференциации

Ключевые слова: достандартная письменость, Православная Славия, диглоссия, славяносербский, методология исследования, моделирование. 